\title{
PATTERN OF SURGICAL CASES AND ITS MANAGEMENT IN BACHA KHAN MEDICAL COMPLEX SHAHMANSOOR SWABI
}

\author{
Arshad Amin ${ }^{1}$, Faiz-Ur-Rahman', Fazli Junaid ${ }^{1}$, Shahid Nisar ${ }^{1}$
}

1. Town Teaching Hospital

\section{ABSTRACT \\ OBJECTIVE}

To study the pattern of general surgery cases and their management in Bacha Khan Medical Complex Shahmansoor Swabi.

\section{METHODS}

This descriptive cases-series study was conducted prospectively in general surgery department Bacha Khan Medical Complex Shahmansoor Swabi form jan, 2013 to Dec, 2015. There were 1200 patients in the series who were managed either conservatively or operated upon. All patients with symptoms suggesting a surgical disease and managed as a surgical case were included, while cases that were referred to other departments and those that left against medical advice were excluded.

\section{RESULTS}

Most of the patients had alimentary tract diseases 361(30\%) followed by urinary tract diseases 264 (22\%), superficial lumps 142 (11.8\%), hernia 140 (11.7\%), hepato-biliary-pancreatic diseases 116 (9.7\%), breast diseases 55 (4.6\%), scrotal diseases 41 (3.4\%), thyroid diseases 28 (2.3\%), salivary gland diseases $15(1.3 \%)$, vascular diseases 8 (0.7\%), thoracic diseases $2(0.2 \%)$ and miscellaneous $28(2.3 \%)$. A total of 604 (64.5\%) patients were treated as elective cases and333 (35.5\%). were treated as emergency cases. As many as 937 (74.08\%) patient were treated by operations and 263 (21.92\%) patients by conservative treatment, while $41(3.41 \%)$ patients were referred. Seven patients expired, giving a mortality rate of $0.58 \%$.

\section{CONCLUSION}

The commonest cause of seeking surgical care was alimentary tract diseases, followed by urinary tract diseases, superficial lumps, hernias, hepato-biliary-pancreatic diseases, breast diseases, scrotal diseases and thyroid diseases. Bacha Khan Medical Complex Shahmansoor Swabi is a newly established hospital catering to the needs of population of district Swabi and adjoining districts and areas.

\section{KEYWORDS}

Surgical cases acute appendicitis, Urinary tract diseases, alimentary tract diseases, haemorrhoid.

\section{INTRODUCTION}

Pakistan has an estimated population of 200 million (July, 2016), which is growing at a rate of $2.05 \%$ per annum and has a rural vs. urban distribution of $64 \%$ vs. $36 \%{ }^{1}$. Total registered medical practitioners in Pakistan till May 31, 2015 are 152792 making doctor to population ratio of 1:12150.2. District Swabi is

Correspondence: Dr. Faiz-Ur-Rahman

Town Teaching Hospital

Contact: 0333-9176048

Email: drfaizdagai@gmail.com

https://doi.org/10.37762/igmds.4-1.26 currently having population of 16 lakh making it the fourth populous district of Khyber Pakhtun Khwa after district Peshawar, Mardan \& Swat. It is becoming very difficult to expand urban services and facilities adequately to cope with the growing pressure of the increasing population. Furthermore the increasing burden of Afghan refugees make the problem even more complicated. Bacha

Khan Medical Complex Shahmansoor Swabi is a 500 bed newly established hospital attached to Gajju Khan Medical College Swabi. Department of surgery comprises of 2 surgical units besides 
the specialties of urology, orthopaedic and neurosurgery. The two surgical unit have 50 bed, each with equal distribution of OPD. operation and emergency days. Bacha khan medical complex shahmansoor swabi mainly attracts peoples from district swabi. As this is the only hospital equipped with professional staff General surgeon, medical specialist, cardiologist, gynecologist, neurosurgeon, orthpaerdic surgeon and urologist in government setup so it attracts peoples from low income areas of Gadoon Amazai, Bunir, attock, Mardan and Haripur districts. Beside this alot number of Afghan Refugees avail the services of this hospital. The pattern of diseases varies with the geographical areas, in different races, age groups, social classes and in people with different occupation. Very few local studies are available on the epidemiology pattern of diseases and incidence of a particular disease prevalent in the district, province and the country. This study was carried out to find out the pattern of cases managed in a surgical department Bacha khan Medical Complex Shahmansoor Swabi.

\section{METHODOLOGY}

This descriptive case-series study is a prospective analysis of all patients treated in surgical department Bacha Khan medical Complex Shahmansoor Swabi. The data was retrieved each month using record from patient's file, admission register and operation theater register. Those patients who were having symptoms suggesting a surgical diseases and treated as a surgical case were included in the study. These patients were either admitted through out-patient department (OPD) Or emergency department or shifted to surgery department from other departments, or operated upon as a day cases. The variables noted and analysed were patient's age, sex, diagnosis, mode of presentation, mode of admission, mode of treatment, nature of operation, complication and final outcome. All the data was analysed using computer program SPSS version-10.

\section{RESULTS}

The patient were enrolled from jan, 2013 to dec, 2015.During the 3-year period 1200 patients were managed either conservatively or operated upon. The gender distribution was: $763(63.58 \%)$ male, 437 $(36.41 \%)$ female. The mean age of the patient was $39.14 \pm 16.6$ year with the range of 2 year to 80 years. The Alimentary tract and urinary tract diseases formed the main bulk of the casestogether accounting for $52 \%$ cases (Table.1) Alimentary tract diseases comprises of non specific abdominal pain, haemorrhoid, Acute appendicitis, anal fissure, anal fistula, intestinal obstruction, ileal perforation, duodenal unlcer perforation, appendicular abscess and carcinoma of gut. Urinary tract diseases comprises of acute UTI renal stone diseases, BPH vesical calculus, non-funcational kidney, urethal stricture, and carcinoma of urinary tract, Superficial lumps(11.8\%)hernias (11.7\%) (12\%) and hepato-biliary-pancreatic diseases $(9.7 \%)$ were the other major diseases. Diseases related to breast $(4.6 \%)$ scrotum $(3.4 \%)$ thyroid $(2.3 \%)$. salivary gland $(1.3 \%)$ vascular $(0.4 \%)$ thoracic $(0.2 \%)$ and of miscellaneous nature. $(2.3 \%)$ accounted for the minority of cases. Out of 937 operations $604(64.5 \%)$ patients were categorized as elective cases while $333(35.5 \%)$ patients as emergency cases $(64.5 \%)$ patients were categorized as elective cases while $426(35.5 \%)$ as emergency cases.

As for the ways of management, $937(78.08 \%)$ patients were managed by operations and 263 (21.92\%) patients by conservative treatment, while $41(3.41 \%)$ patients were referred.

In terms of operations performed in this series appendicectomy was the most common surgery. Uncomplicated hernia surgery $(15 \%)$ was the $2^{\text {nd }}$ most common procedure and included herniotomy, herniorrhaphy, and hernioplasty. The $3^{\text {rd }}$ most common procedure was excision of various subcutaneous lumps (13\%) including carbuncle. Fourth on the lest was haemorrhoidectomy, other common operations were cholecystectomy, urinary trach surgery and incision and drainage procedures. 


\section{DISCUSSION}

The spectrum of diseases is generally considered a reflection of disease prevalence in a region. In this series, alimentary tract diseases (30.08) were the most prominent cause of admission, followed by urinary tract diseases $(22 \%)$,superficial lumps $(11.8 \%)$ hernia $(11.7 \%)$, hepate-biliary-pancreatic diseases $(9.7 \%)$, breast diseases $(4.6 \%)$, scrotal diseases $(3.4 \%)$, thyroid diseases $(2.3 \%)$, salivary gland diseases $(1.3 \%)$ vascular diseases $(0.7 \% \quad)$ thoracic diseases $(0.2 \%)$, and miscellaneous $(2.3 \%)$. In a report form the American Board of Surgery, the average number of procedures performed by general surgeons were: abdomen (hepato-biliary-pancreatic + hernia) $26 \%$, alimentary tract $16 \%$, breast $14 \%$ endoscopy $13 \%$ skin/soft tissue $12 \%$ and vascular $10 \%$ however, genitourinary tract, thoracic and endocrine procedures accounted for $1 \%$ each. ${ }^{4}$

Appendicectomy (17.6\%) was the most common operation in our study. It usually runs in families and is common in those peoples who consume lessfibre in their diet. Since in Bacha Khan Medical Complex Shahmansoor Swabi the patients usually come from far flung areas so in ordered to avoid complication of acute appendicitis eg the risk of rupture these patient are usually preferred to be operated upon rather than sent back home without operation.Interestingly a case of suspected appendicitis was opened but the appendix was found absent after thorough search of retrocacecal and ileal regions. Three more senior surgeons were called upon to confirm the absence of appendix was declared as congenital absence of appendix in that particular patient. Such cases are rarely reported from other part of the world. The incidence is estimated to be one in 1,00,000 laparotomies for suspected appendicitis.A cute appendicitis is among the most frequent causes of surgical abdominal diseases worldwide ${ }^{13,14}$ Another study from Ghana also reported appendicitis as the most common cause of acute abdomen (23.5\%), followed by non-specific abdominal pain $(21.4 \%)$, acute intestinal obstruction (10.8\%), gynaecological causes $(9.5 \%)$ and peptic ulcer $(9.2 \%) .{ }^{15}$ Caterino from Rome reported appendicitis as the most frequent diagnosis $(16.4 \%)$ followed by non-specific abdominal pain $(15.5 \%)$, Cholelithiasis (12.5\%) abdominal malignancy $(10.3 \%)$. ${ }^{16}$ Hernia surgery $(15 \%)$ turned out to be the $2^{\text {nd }}$ most common surgical operation in this series, which was in line with several other international studies ${ }^{4-7}$. Excision of superficial lumps is also a common operation performed in over setup the spectrim ranges from lipoma to soft tissue sarcoma and infections of superficial tissue. The next most common disease requiring a surgical procedure was haemorrhoids $(7.7 \%)$, a finding which is not reported earlier in any rural international series. The estimated prevalence rate of symptomatic haemorrhiods in the United States is $(4.4 \%)$ of the adult population. ${ }^{8}$ The othert common surgical disease in this series was gallstone disease (6.4\%). Abu-Eshy et al reported the overall prevalence of gallstone disease in Saudi Arabia as $11.7 \%{ }^{9}$ Gallstone disease remains one of the most common medical problems leading to surgical intervention. Cholelithiasis affects approximately $10 \%$ of the adult population in the United states. ${ }^{10}$. In this series the most common cause of acute abdominal admission was acute urinary tract infection (UTI) $9.4 \%$, followed by non-specific abdominal pain $7.2 \%$, acute appendicitis $4.8 \%$, acute urinary retention $2.4 \%$, acute intestinal abstruction $2 \%$, ileal perforation $0.6 \%$, and duodenal perforation $0.4 \%$. Ohene-Yeboah in an study from Ghana reported the following 7 conditions as the most common causes of acute abdominal pain requiring admission: acute intestinal obstruction (12.6\%), gastroduodenal perforations (11.0\%) non-specific abdominal pain $(9.8 \%)$ abdominal injures (8.3\%) and acute cholecystitis $(3.2 \%) .{ }^{11}$ Chianakwana et al in an study from Nigeria reported appendicectomy as the most common emergency operation in 139 patients, followed by road traffic accidents (RTAs) involving 137 patients, gunshot injuries mainly from armed robbery attacks 127 cases, acute intestinal obstruction 92 cases. ${ }^{12}$.In over study RTA patients or not included because they are not entertained due to lack of infrastructure like ICU, blood bank, trauma center and professional trauma team these patients are referred to tertiary care hospital .The frequency of renal stone disease in patients with urinary tract infection was earlier reported from charsadda, Pakistan, as $18.98 \% .{ }^{17}$ Acute pyelonephritis is a frequent condition responsible for more than 100,000 hospitalisations per year in the United States. ${ }^{18}$ Skin and soft tissue infections are common diseases, as noted in this series. The spectrum ranges from mild boil to severe necrotising soft tissue infection, as reported in other international studies, ${ }^{19,20}$ Similarly, grampositive bacteria accounted for more than $80 \%$ of the cases. ${ }^{19}$ Diseases of the breast are common and include 
problems, related to pregnancy and lactation, inflammatory conditions, non-neoplastic proliferative and benign neoplastic disorders $59.5 \%$ and malignant neoplasms.. An earlier study from several district (nonteaching) hospitals from rural areas of Pakistan showed the following spectrum: hernia surgery $(8.7 \%)$, urinary calculus removal $(6.2 \%)$, appendicectomy $(5 \%)$, haemorrhoid or perianal surgery $(4 \%)$, prostatectomy $(4 \%)$, abscess drainage (3.5\%), gastrointestinal operations (3.1\%), excision of skin and subcutaneous lesions $(2.9 \%)$, hydrocele operation $(0.9 \%)$, gallbladder/biliary operation $(0.6 \%)$, breast surgery $(0.6 \%)$ and scrotal/testicular operation $(0.6 \%) .^{7}$. In this series 41 patients were referred to urban tertiary care institutions. The referred cases included mostly malignancies (oesophagus, stomach, rectum, kidney, bladder, prostate and thyroid), as well as cases of acute pancreatitis and choledocholithiasis.

\section{REFERENCES}

1. Annual plan 2010-11, planning commission, Govt. of Pakistan: chapter 9, population \& development. (Online) 2010 (Cited 2010 july 24). Available from URL:

http://www.planningcommission.gov.pk/annual\%20plans/201011/population\%20and\%20Development.pdf.

2. Statistics: Pakistan medical \& dental council. (Online) 2005 (cited 2010 july 24). Available from URL: http://www.pmc.org.pk/statistics/tabid/103/default.aspx.

3. Final report: Karachi mega cities preparation project. (Online) 2005 (cited 2010 july 25). Available from URL: http://www.adb.org/Documents/Produced-Under-TA/38405/38405-PAK-DPTA.pdf.

4. Ritchie WP jr, Rhodes RS, Biester TW. Workloads and practice patterns of general surgeons in the United States, 1995-1997: a report from the American Board of surgery. Ann Surg 1999; 230: 53342.

5. Humber N, Frecker T. Rural surgery in British Columbia: is there anybody out there? Can j surg 2008; 51: $179-84$.

6. Awojobi OA. Principle of rural surgical practice. Dokita 1998; 25: 161-2.

7. Blanchard RJ, Blanchard ME, Toussignant $P$, ahmed M, Smythe CM. the epidemiology and spectrum of surgical care in district hospitals of Pakistan. Am J Public Health 1987; 77: 143-45.

8. Schubert MC, Sridhar S, schade RR, wexner SD. What every gastroenterologist needs to know about common anorectal disorders. World J Gastroenterol 1009; 15:3201-9.

9. Abu-Eshy SA, Mahfouza AA, Badr A, El Gamal MN, Al-Shehri MY, Salati MI, et al. Prevalence and risk factors of gallstone disease in a high altitude. Saudi population. East mediterr health 2007; J 13: 794-802.

10. Schirmer BD, winters KL, Edlich RF. Cholelithiasis and cholecystitis. $J$ Long term Eff med implants 2005; 15: 329-38.

11. Ohene-Yeboah M Acute surgical admissions for abdominal pain in adults in Kumasi, Ghana. ANZ J Surg 2006; 76: 898-903.

12. Chianakwana GU, ihegihu CC, okafor PI, anyanwu SN, Mbonu OO. Adult surgical emergencies in a developing country: the experience of Nnamdi Azikiwe University Teaching Hospital, Nnewi, Anambra state, Nigeria. World J surg 2005; 29: 804-7. 
13. Noudeh YJ, Sadigh N, Ahmadnia AY. Epidemiologic features, seasonal variations and false positive rate of acute appendicitis in shahr-e-Rey, Tehran. Int J surg 2007; 5: 95-8.

14. Davies GM, Dasbach EJ, Teutsch S. The burden of appendicitis-related hospitalizations in the United States in 1997. Surg infect (Larchmt) 2004; 5:160-5.

15. Naaeder SB, Archampong EQ. Clinical spectrum of acute abdominal pain in Accra, Ghana. West Afr J Med 1999; 18:13-6.

16. Caterino S, Cavallini M, Mali C, Murante G, Schiffino L, Lotito S, Toncher F. Acute abdominal pain in emergency surgery: clinical epidemiologic study of 450 patients. Ann ital Chir 1997; 68:807-17.

17. Jan H, Akbar I, Kamran H, Khan J. Frequency of renal stone disease in patients with uinary tract infection. J Ayub Med Coll Abbottabed 2008; 20: 60-2.

18. Rollino C. Acute pyelonephritis in adults. G Ital Nefrol 2007; 24: 121-31.

19. Kujath P, Eckmann C, Bouchard R, Esnaasheri H. Complicated skin and soft tissue infections. Zentraibl chir 2007; 132 411-8.

20. Gabillot-Carre M, Roujeau JC. Acute bacterial skin infections and cellulitis. Curr opin infect Dis 2007; 20: 118-23.

21. Mayun AA, Pindiga UH, Babayo UD. Pattern of histopathological diagnosis of breast lesions in Gombe, Nigeria. Niger J Med 2008; 17:159-62.

22. Agarwal G, Pradeep PV, Aggarwal V, Yip CH, Cheung PS. Spectrum of breast cancer in Asian women. World J Surg 2007; 31: 1031-40.

23. Hays RB, Evans RJ, Veitch $C$. The quality of procedural rural medical practice in Australia. Rural Remote Health 2005; 5: 474.

\section{Corrigendum}

In the issue Vol. 03 No.02 (March 2017-September 2017) of JGMDS in the article titled "Effectiveness of disk in the treatment of herniated lumbar intervertebral disc.", the name of the authors were aberrantly printed by omitting two authors. Henceforth the author list for the said article should be read as under=

\section{Sohail Amir ${ }^{1}$, Maimoona Qadir², Muhammad Usman ${ }^{3}$ \\ 1. Naseer Teaching Hospital, Peshawar. \\ 2. Khyber Teaching Hopital, Peshawar. \\ 3. Naseerullah Babar Memorial Hospital, Peshawar.}

LICENSE: JGMDS publishes its articles under a Creative Commons Attribution Non-Commercial Share-Alike license (CC-BY-NC-SA 4.0) COPYRIGHTS: Authors retain the rights without any restrictions to freely download, print, share and disseminate the article for any lawful purpose. It includes scholarly networks such as Research Gate, Google Scholar, LinkedIn, Academia.edu, Twitter, and other academic or professional networking sites. 